\title{
Factors affecting expression of estrus in dairy cows with high milk yields
}

\author{
AURIMAS GAVELIS, VYTUOLIS ŽILAITIS, ARŪNAS JUOZAITIS, \\ VIDA JUOZAITIENE், GIEDRIUS PALUBINSKAS, AYHAN YILMAZ*
}

\begin{abstract}
Lithuanian University of Health Sciences, Veterinary Academy, Kaunas, Lithuania *Siirt University, Agricultural Faculty, Department of Animal Science, Siirt, Turkey
\end{abstract}

Gavelis A., Žilaitis V., Juozaitis A., Juozaitienė V., Palubinskas G., Yilmaz A. Factors affecting expression of estrus in dairy cows with high milk yields

Summary

The objectives of this study were to define the effect of the milk progesterone (P4) concentration on estrus expression in dairy cows with high milk yield and to identify the effect of milk yield and parity on the milk P4 concentration and cow's pregnancy after artificial insemination (AI). In this study, 48 clinically healthy cows without reproduction disorders, on day 90-100 after calving were used. At the beginning of estrus and 12 hours after the beginning of estrus, the milk P4 concentration in dairy cows with high milk yield (group 3 ) was higher than in group $2(33.66 ; 22.36 \%)$ and in group $1(51.60 ; 65.26 \%)(P<0.001)$. The milk $P 4$ concentration in the $\geq 3$ lactation cows was higher than the second $(13.45 \% ; P>0.05)$ and the first $(28.28 \% ; P<0.01)$ lactation ones $(28.28 \% ; P<0.01)$. The milk $\mathbf{P} 4$ concentration at the beginning of estrus and 12 hours after the beginning of estrus in pregnant and non-pregnant cows was 2.58 and $3.32 ; 4.20$ and $5.00 \mathrm{ng} / \mathrm{ml}$, respectively (P $<0.001)$. As a result, it was concluded that high progesterone concentration affected the expression of estrus and pregnancy results in dairy cows, and the measuring of progesterone concentration in milk can be used as a non-invasive method to provide detailed information about fertility in high milk yield cows.

Keywords: dairy cows, estrus expression, milk progesterone, yield, parity

An increased level of production in dairy cows can lead to reduction of time and intensity of estrus expression $(23,24)$. Kurykin et al. (22) reported that a delay in the resumption of cycling in cows after calving, weak estrus expression, and low detection rates of estrus have been the major factors limiting reproductive performance on dairy farms. Similarly, Dobson et al. (13) stated that the pattern of estrus expression-standing to be mounted in dairy cows with high milk production has changed over the past half century. Many studies had shown the tendency of the dairy cows with high breeding value for milk yield of a delayed return to a normal ovarian cycle, reduced heat expression, increased silent estrus, poor conception rates, and inappropriate timing of insemination (10, $12,16,40)$. Basically, high yield cows may be better adapted to mobilize body energy reserves to ensure nutrient availability for milk production, which may have a negative effect on fertility (17). At the same time, it was observed that the lactation number has a significant effect on reproduction performance in dairy cows. It is reported that heifers ovulate a little earlier after the onset of estrus than cows (29). In another study it was pointed out that, depending on cattle breed, an atypical P4 cycle was less frequent in older cows (30).

P4 is an important regulator of events during the estrus cycle and a key hormone for successful pregnancy in ruminants $(2,11,18,38)$. An increased concentration of $\mathrm{P} 4$ on the day of AI was related to the decreased non-return-rate $(4,37,39)$, possibly due to a negative effect of elevated P4 on oocyte maturation and ovulation (14). During mid diestrus, the $\mathrm{P} 4$ concentration in lactating dairy cows fluctuated between 4.0 and $5.8 \mathrm{ng} / \mathrm{mL}$ (34). It was stated that P4 monitoring was an indicator for determining errors in estrus detection and potential silent heats $(19,27)$. Such a non-invasive method is the measuring of the P4 concentration in milk to obtain detailed information about the fertility status of a cow (7).

The purpose of this study was to define the effect of the milk P4 concentration on estrus expression in dairy cows with high milk yield. Another aim was to detect the effect of milk yield and the parity on the milk P4 concentration and a cow's pregnancy after insemination. 


\section{Material and methods}

In this study, 48 clinically healthy cows without reproduction disorders, on day 90-100 after calving were used. Milk yield of the cows was calculated using the herd management software of the integrated DeLaval DelPro ${ }^{\mathrm{TM}} 4.2$ dairy farm management system. Milk yield of the cows used in the study varied from 13.7 to $61.4 \mathrm{~kg}$ per day. Based on milk yield, the cows were classified into the following three groups: group $1(<30)$, group $2(30-45)$ and group $3(>45)$. At the same time, the cows were broken into the following three lactation categories by parity: the first lactation cows $(\mathrm{n}=22)$, the second lactation cows $(\mathrm{n}=10)$, and $\geq 3$ lactations cows $(n=16)$.

Identification of estrus signs. The cows were monitored for 21 days during their estrus, on a daily basis, for half an hour after morning and evening milking. The signs of estrus in cows were detected according to the following features: the reduced milk yield, liquid mucus (the first sign of estrus), mounting behavior, and sticky mucus of the vagina. All cows were inseminated within 12 hours from the appearance of the first signs of estrus.

$\mathbf{P} 4$ concentration in milk. Milk samples for $\mathrm{P} 4$ concentration were taken from the cows on heat after milking and stored in plastic containers $(50 \mathrm{ml})$. The samples were taken for a second time at the beginning of estrus and 12 hours after the beginning of estrus. The $\mathrm{P} 4$ concentration in milk samples was analyzed 2 hours after sampling, using the Hormonost ${ }^{\circledR}$ milk set produced by BioLab GmbH (Munich).

Statistical analysis. The data were analyzed using SPSS (Statistical Package for the Social Sciences, 20.0). The findings were provided as average value and standard error. The Pearson product-moment correlation coefficient was calculated and the Chi-square test was performed to identify the statistical differences among the groups. The differences in mean values of normal distributed traits were analyzed by the Student's $t$ test.

\section{Results and discussion}

Milk P4 concentration and estrus time. Expression of behavioral estrus depends on several factors, such as hormonal concentrations and physiological and environmental factors (35). It has been concluded that there was a discrepancy relation between fertility, milk yield, and milk composition of dairy cows with high milk yield $(5,20)$.

In the present study, average $\mathrm{P} 4$ concentration in milk was $3.254 \pm 0.1279 \mathrm{ng} / \mathrm{ml}$. The concentrations of $\mathrm{P} 4$ in milk were 2.85 and $3.66 \mathrm{ng} / \mathrm{ml}$ at the beginning of estrus and 12 hours after the beginning of estrus, respectively $(\mathrm{P}<0.01)$.

In the current study, it was found that the milk P4 concentration was related to increasing milk yield in dairy cows $(\mathrm{r}=0.738 ; \mathrm{P}<0.0001)$, and the $\mathrm{P} 4$ concentration in milk had an increase according to linear dependence equation (Fig. 1).

The dairy cows with high milk yield (group 3 ) had a higher P4 concentration in milk (4.77 $\pm 0.2922 \mathrm{ng} /$ $\mathrm{ml})$. The $\mathrm{P} 4$ concentration in this group was higher in

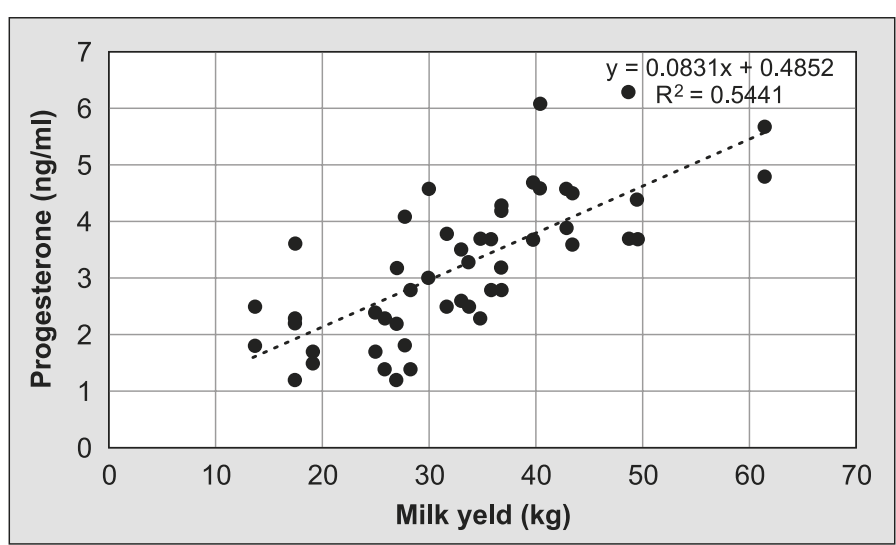

Fig. 1. Relationship between P4 concentration and milk yield

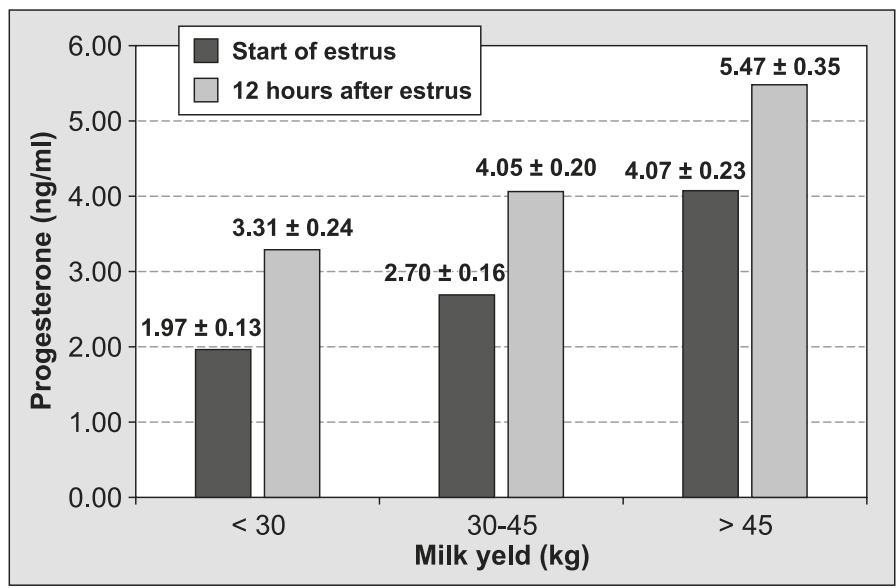

Fig. 2. P4 concentration in cows with different milk yield

comparison with that in group 1 (2.04 times) and in group 2 (1.29 times) $(\mathrm{P}<0.001)$.

At the beginning of estrus (Fig. 2), average milk P4 concentration in dairy cows with high milk yield (group 3) was higher by 33.66\% $(\mathrm{P}<0.001)$ compared to that in group 2 , and lower by $51.60 \%(\mathrm{P}<0.0001)$ than the P4 concentration in group 1. It was also defined that 12 hours after the beginning of estrus, the milk P4 concentration in group 1 was lower by $22.36 \%$ $(\mathrm{P}<0.001)$ than that in group 2 , and lower by $65.26 \%$ $(\mathrm{P}<0.0001)$ than in group 3 of the researched cows.

A significant correlation was established between the milk $\mathrm{P} 4$ concentration and milk yield at the beginning of the estrus $(\mathrm{r}=0.847 ; \mathrm{P}<0.01)$ and 12 hours after the beginning of estrus $(\mathrm{r}=0.743 ; \mathrm{P}<0.01)$.

It was defined that the dairy cows with high milk yield had a higher milk $\mathrm{P} 4$ concentration $(\mathrm{P}<0.001)$. The cows a with low milk $\mathrm{P} 4$ concentration were more likely to express estrus than the ones with a high P4 concentration. It was identified that the sub-population of low P4 cows that expressed estrus had larger preovulatory follicles and greater P4 concentrations after the timed AI (15). According to the observations of former researchers, the decrease of milk yield in postconception dairy cows is related to hormonal changes $(1,3)$. Khan et al. (21) reported that, as determined by the milk P4 profiles, when milk yields increase by 
$7 \%-17 \%$, the incidence of persistent corpora lutea in such cows is more frequently observed $(26,32)$. Nebel et al. (28) reported that the time of estrus in lactating dairy cows was reduced by 8 hours. High yield cows are more likely to have suboptimal concentrations of P4 (6).

Milk P4 concentration and lactation number. Average milk P4 concentration in the first, the second, and the $\geq 3$ lactation cows was $2.9 \pm 0.15 \mathrm{ng} / \mathrm{ml}, 3.29$ $\pm 0.24 \mathrm{ng} / \mathrm{ml}$, and $3.72 \pm 0.27 \mathrm{ng} / \mathrm{ml}$, respectively. The milk P4 concentration in the $\geq 3$ lactation cows was higher by $28.28 \%(\mathrm{P}<0.01)$ than that in the first lactation ones, and higher by $13.45 \%(\mathrm{P}>0.05)$ than in the second lactation cattle (Fig. 3). The milk P4 concentration in the $\geq 3$ lactation cows was higher than that in the first lactation $(5.41 \%)$ and in the second lactation (9.31\%) ones.

At the beginning of estrus, the milk P4 concentration in the first lactation cows was less than that in the second $(8.87 \% ; \mathrm{P}>0.05)$ and the $\geq 3$ lactation ones $(38.71 \% ; \mathrm{P}<0.01)$. Similarly, 12 hours after the beginning of estrus, the milk $\mathrm{P} 4$ concentration in group 3 was higher compared with group $2(16.87 \%)$ and group 1 $(20.48 \%)$. However, the differences among those lactation levels were statistically insignificant $(\mathrm{P}>0.05)$.

The fertility level of the first lactation cows may be lower than that of older cows (42). On the other hand, the effect of parity on peripheral $\mathrm{P} 4$ production is still unclear (5). Nevertheless, it was generally acknowledged that the increase in lactation number leads to reproductive issues and metabolic disorders (8).

In this study it was defined that the $\mathrm{P} 4$ concentration in $\geq 3$ lactation cows was higher than in the second $(\mathrm{P}>0.05)$ and the first lactation ones $(\mathrm{P}<0.01)$. In contrast, Petersson et al. (30) reported that the risk of atypical profiles for $\mathrm{P} 4$ concentration in dairy cows was 0.5 and 0.7 times lower for older cows compared with the first lactation ones. It was noticed that heifers' pregnancy rate $(\mathrm{PR})$ during the first insemination was higher $(67.9 \%)(\mathrm{P}<0.05)$ compared to that of the first $(42.9 \%)$, the second $(20.0 \%)$ and the $\geq 3$ lactation cows. In the same study it was reported that between

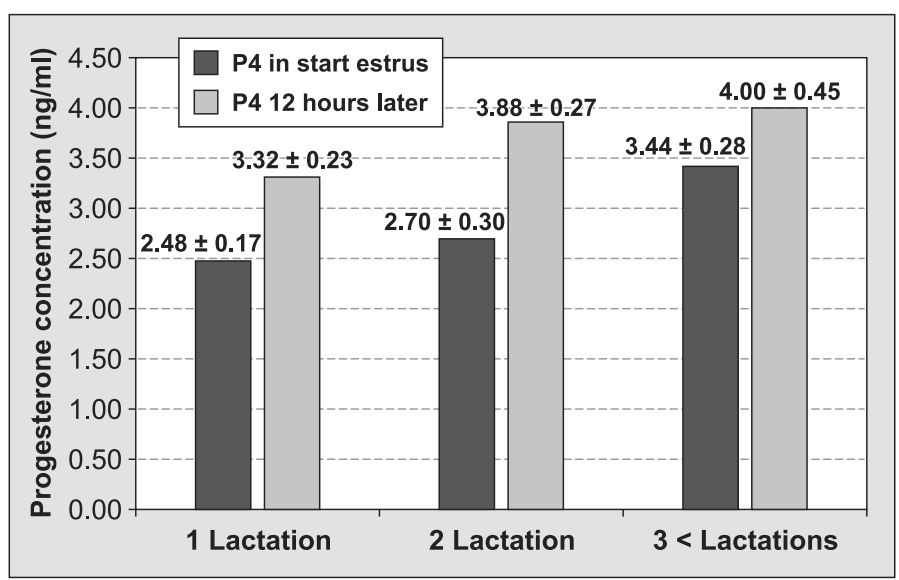

Fig. 3. P4 concentration based on lactation number lactation levels of cows there were no differences for P4 concentration. In the study, the analyses of P4 concentration had shown that one of 10 heifers $(10 \%)$ was omitted unanalyzed, whereas 3 of $10(30 \%)$ in the first, the second and the $\geq 3$ lactation cows were omitted unanalyzed due to short cycles or prolonged low P4 concentrations (5).

This study clearly demonstrated that parity had a significant effect on PR. The finding was in agreement with the related studies provided in the literature $(9$, 31), where it was reported that compared to heifers the PR of mature cows was lower. Similarly, Wolfenson et al. (41) reported that there were significant differences in peripheral $\mathrm{P} 4$ concentration between heifers and cows.

Milk P4 concentration and pregnancy. The conception rate in dairy cows used in this study was $79.2 \%$. The milk P4 concentrations at the beginning of estrus and 12 hours after the beginning of estrus in pregnant cows were 2.58 and $3.32 \mathrm{ng} / \mathrm{ml}$, respectively. The milk P4 concentrations at the beginning of estrus and 12 hours after the beginning of estrus in non-pregnant cows were 4.20 and $5.00 \mathrm{ng} / \mathrm{ml}$, respectively. There were significant differences between pregnant and non-pregnant cows in terms of milk $\mathrm{P} 4$ concentration $(\mathrm{P}<0.001)$.

At the same time, milk yield in non-pregnant and pregnant cows in relation to pregnancy results is presented in Table 2.

Table 2 shows that there are significant differences between non-pregnant and pregnant cows in terms of milk yield ( $\mathrm{P}<0.001)$. The findings of this study have clearly shown that a high $\mathrm{P} 4$ concentration in dairy cows causes silent estrus. Similar findings were provided by Samad et al. (33), who reported that to achieve higher pregnancy levels, cattle and buffalo should be inseminated when the progesterone concentration is lowest, while López-Gatius et al. (25) reported that in all cows plasma progesterone levels on the day of

Tab. 1. $\mathbf{P} 4$ concentration $(\mathrm{ng} / \mathrm{ml})$ in dairy cows according to results of pregnancy

\begin{tabular}{|l|c|}
\hline P4 concentration at the beginning of estrus & $X \pm S E$ \\
\hline Non-pregnant & $4.20 \pm 0.29$ \\
Pregnant & $2.58 \pm 0.15$ \\
\hline P4 concentration 12 hours after the beginning of estrus & $X \pm S E$ \\
\hline Non-pregnant & $5.00 \pm 0.40$ \\
\hline Pregnant & $3.32 \pm 0.20$ \\
\hline
\end{tabular}

Explanation: $* * *-\mathrm{P}<0.0001$

Tab. 2. Milk yield (kg) based on results of pregnancy

\begin{tabular}{|l|c|}
\hline Results of pregnancy & $\mathrm{X} \pm \mathrm{SE}$ \\
\hline Non-pregnant & $44.800 \pm 3.011$ \\
Pregnant & $30.316 \pm 1.544$ \\
\hline
\end{tabular}

Explanation: $* * *-\mathrm{P}<0.001$ 
AI were lower than $0.5 \mathrm{ng} / \mathrm{ml}$. On the other hand, an adequate concentration of $\mathrm{P} 4$ is required for a successful pregnancy of cows. Siregar et al. (36) clearly indicated that a low concentration of P4 is one of the main factors causing the death of embryos.

Finally, the conclusion was made that the milk P4 concentration and lactation number predetermine the expression of estrus and pregnancy results of high milk yield dairy cows. Additionally, it was asserted that measuring the $\mathrm{P} 4$ concentration in milk can be used as a non-invasive method to provide detailed information on high milk yield cows.

\section{References}

1. Akers R. M.: Major advances associated with hormone and growth factor regulation of mammary growth and lactation in dairy cows. J. Dairy. Sci. 2006, 89, 1222-1234.

2. Arndt W. J., Holle A. J., Bauer M. L., Kirsch J. D., Schimek D. E., Odde K. G., Vonnahme K. A.: Effect of post-insemination progesterone supplementation on pregnancy rate in dairy cows. Can. J. Vet. Res. 2009, 73, 271-274.

3. Bachman K. C., Hayen M. J., Morse D., Wilcox C. J.: Effect of pregnancy, milk yield, and somatic cell count on bovine milk fat hydrolysis. J. Dairy. Sci. 1988, 71, 925-931

4. Båge R.: Conception rates after AI in Swedish red and white dairy heifers: Relationship with P4 concentrations at AI. Reprod. Domest. Anim. 2003, 38, 199-203.

5. Balendran A., Gordon M., Pretheeban T., Singh R., Perera R., Rajamahedran R.: Decreased fertility with increasing parity in lactating dairy cows. Can. J. Anim. Sci. 2008, 88, 425-428.

6. Bech-Sàbat G., López-Gatius F., Yániz J. L., Garcia-Ispierto I., Santolaria P., Serrano B., Sulon, J., de Sousa N. M., Beckers J. F.: Factors affecting plasma progesterone in the early fetal period in high producing dairy cows. Theriogenology 2008, 69, 426-432.

7. Boldt A., Kanitz W., Martin G., Losand B., Römer A.: Progesterone in milkinvestigations on practicability as a functional trait in dairy cows. Conference: ICAR/INTERBULL Conference 19-23 May, At Berlin, Germany 2014, OP-23, 52.

8. Bonneville-Hébert A., Bouchard E., Tremblay D. D., Lefebvre R.: Effect of reproductive disorders and parity on repeat breeder status and culling of dairy cows in Quebec. Can. J. Vet. Res. 2011, 75, 147-151.

9. Butler W. R., Smith R. D.: Interrelationships between energy balance and postpartum reproductive function in dairy cattle. J. Dairy. Sci. 1989, 72, 767-783.

10. Crowe M. A.: Resumption of ovarian cyclicity in post-partum beef and dairy cows. Reprod. Domest. Anim. 2008, 43, 20-28.

11. Diskin M. G., Morris D. G.: Embryonic and early foetal losses in cattle and other ruminants. Reprod. Domest. Anim. 2008, 43, 260-267.

12. Dobson H., Smith R. F., Royal M. D., Knight C. H., Sheldon I. M.: The highproducing dairy cow and its reproductive performance. Reprod. Domest. Anim. 2007, 42, 17-23.

13. Dobson H., Walker S. L., Morris M. J., Routly J. E., Smith R. F.: Why is it getting more difficult to successfully artificially inseminate dairy cows? Animal 2008, 2, 1104-1111.

14. Fair T., Lonergan P.: The role of progesterone in oocyte acquisition of developmental competence. Reprod. Domest. Anim. 2012, 47, 142-147.

15. Fricke P. M., Carvalho P. D., Lucy M. C., Curran F., Herlihy M. M., Waters S. M., Larkin J. A., Crowe M. A., Butler S. T.: Effect of manipulating progesterone before timed artificial insemination on reproductive and endocrine parameters in seasonal-calving, pasture-based Holstein-Friesian cows. J. Dairy. Sci. 2016, 99, 6780-6792.

16. Friggens N. C., Chagunda M. G.: Prediction of the reproductive status of cattle on the basis of milk P4 measures: Model description. Theriogenology 2005, 64, 155-190.

17. Gutierrez C. G., Gong J. G., Bramley T. A., Webb R.: Selection on predicted breeding value for milk production delays ovulation independently of changes in follicular development, milk production and body weight. Anim. Reprod. Sci. 2006, 95, 193-205.

18. Hansen P. J.: Challenges to fertility in dairy cattle: from ovulation to fetal stage of pregnancy. Bras. Reprod. Anim. 2011, 35, 229-238.

19. Harrison R. O., Ford S. P., Young J. W., Conley A. J., Freeman A. E.: Increased milk production versus reproductive and energy status of high producing dairy cows. J. Dairy. Sci. 1990, 73, 2749-2758.
20. Kadri N. K., Sahana G., Charlier C., Iso-Touru T., Guldbrandtsen B., Karim L., Nielsen U. S., Panitz F., Aamand G. P., Schulman N., Georges M., Vilkki J., Lund M. S., Druet T.: A 660-Kb deletion with antagonistic effects on fertility and milk production segregates at high frequency in Nordic Red cattle: additional evidence for the common occurrence of balancing selection in livestock. PLoS Genetics 2014, 10, e1004049.

21. Khan S., Qureshi M. S., Ahmad N., Amjed M., Younas M., Rahman A.: Feed supplementation prevents post-conception declinein milk progesterone concentrations associated with production stress in dairy buffaloes (Bubalus bubalis). Trop. Anim. Health. Prod. 2009, 41, 1133-1142.

22. Kurykin J., Jalakas M., Kaart T., Jaakma Ü.: Efficiency of insemination with sexed semen at spontaneous estrus and synchronization of ovulation in lactating Holstein cows. Vet. Med. Zoot. 2017, 75, 30-35.

23. Lopez H., Caraviello D. Z., Satter L. D., Fricke P. M., Wiltbank M. C.: Relationship between level of milk production and multiple ovulations in lactating dairy cows. J. Dairy. Sci. 2005, 88, 2783-2793.

24. Lopez H., Satter L. D., Wiltbank M. C.: Relationship between level of milk production and estrous behavior of lactating dairy cows. Anim. Reprod. Sci. 2004, 81, 209-223.

25. López-Gatius F., López-Helguera I., de Rensis F., Garcia-Ispierto I.: Effects of different five-day progesterone-based synchronization protocols on the estrous response and follicular/luteal dynamics in dairy cows. J. Reprod. Dev. 2015, $61,465-471$.

26. Lucy M. C.: Reproductive loss in high-producing dairy cattle: where will it end? J. Dairy. Sci. 2001, 84, 1277-1293.

27. Nebel R. L.: On-farm milk Progesterone tests. J. Dairy. Sci. 1988, 71, 1682 -1690 .

28. Nebel R. L., Dransfield M. G., Jobst S. M., Bame J. H.: Automated electronic systems for the detects of oestrus and timing of AI in cattle. Anim. Reprod. Sci. 2000, 60-61, 713-723.

29. Noakes D. E., Parkinson T. J., England G. C.: Veterinary reproduction and obstetrics. $9^{\text {th }}$ ed., Elsevier Health Sciences, Edinburgh 2009.

30. Petersson K. J., Gustafsson H., Strandberg E., Berglund B.: Atypical progesterone profiles and fertility in Swedish dairy cows. J. Dairy. Sci. 2006, 89, 2529-2538.

31. Pryce J. E., Royal M. D., Garnsworthy P. C., Mao I. L.: Fertility in highproducing dairy cow. Livest. Prod. Sci. 2004, 86, 125-135.

32. Royal M. D., Darwash A. O., Flint A. P. F., Webb R., Wooliams J. A., Lamming $G$. E.: Declining fertility in dairy cattle: changes in traditional and endocrine parameters of fertility. Anim. Sci. 2000, 70, 487-501.

33. Samad H. A., Ahmad N., Bengmen and Rehman N. U.: Use of milk progesterone assay for monitoring oestrus and early pregnancy in Nili-Ravi buffaloes. Pakistan. Vet. J. 2004. 24, 121-124.

34. Sartori R., Haughian J. M., Shaver R. D., Rosa G. J., Wiltbank M. C.: Comparison of ovarian function and circulating steroids in estrous cycles of Holstein heifers and lactating cows. J. Dairy. Sci. 2004, 87, 905-920.

35. Senger P. L.: The estrus detection problem: New concepts, technologies, and possibilities. J. Dairy. Sci. 1994, 77, 2745-2753.

36. Siregar T. N., Wajdi F., Akmal M., Fahrimal Y., Adam M., Panjaitan B., Sutriana A., Daud R., Armansyah T., Meutia N.: Embryonic death incidents due to heat stress and effect of therapy with gonadothropin releasing hormone $(\mathrm{GnRH})$ in aceh cattle. Vet. Med. Zoot. 2017, 75, 70-74.

37. Souza A. H., Gümen A., Silva E. P., Cunha A. P., Guenther J. N., Peto C. M., Caraviello D. Z., Wiltbank M. C.: Supplementation with Estradiol-17 $\beta$ before the last gonadotropin releasing hormone injection of the Ovsynch protocol in lactating dairy cows. J. Dairy. Sci. 2007, 90, 4623-4634.

38. Spencer T. E., Johnson G. A., Bazer F. W., Burghardt R. C., Palmarini M.: Pregnancy recognition and conceptus implantation in domestic ruminants: roles of progesterone, interferons and endogenous retroviruses. Reprod. Fertil. Dev. 2007, 19, 65-78.

39. Waldmann A., Reksen O., Landsverk K., Kommisrud E., Dahl E., Refsdal A. O., Ropstad E.: Progesterone concentrations in milk fat at first insemination effects in non-return and repeat breeding. Anim. Reprod. Sci. 2001, 65, 33-41.

40. Walsh S. W., Williams E. J., Evans A. C.: A review of the causes of poor fertility in high milk producing dairy cows. Anim. Reprod. Sci. 2011, 123, 127-138.

41. Wolfenson D., Inbar G., Roth Z., Kaim M., Bloch A., Braw-Tal R.: Follicular dynamics and concentrations of steroids and gonadotropins in lactating cows and nulliparous heifers. Theriogenology 2004, 62, 1042-1055.

42. Wu J., Brickell J. S., Yang L. G., Cheng Z., Zhao H. Q., Wathes D. C., Zhang S. J.: Reproductive performance and survival of Chinese Holstein dairy cows. Anim. Prod. Sci. 2012, 52, 11-19.

Corresponding author: PhD student Aurimas Gavelis, Kaunas LT-47181, Lithuania; e-mail: aurimas.gavelis@Ismuni.It 